\title{
Teachers' Perception in Writing Action Research in a Public Elementary School in the Philippines
}

\author{
Geraldine D. Anzaldo ${ }^{1} \&$ Mario A. Cudiamat $^{2}$ \\ ${ }^{1}$ Talisay Elementary School, Calatagan District, Department of Education-Batangas, Philippines \\ ${ }^{2}$ Research and Statistics Center, Senior High School in Calatagan, Department of Education-Batangas, Philippines \\ Correspondence: Geraldine D. Anzaldo, Talisay Elementary School, Calatagan District, Department of Education- \\ Batangas, Philippines. Tel: 0955-762-4434. E-mail: geraldine.anzaldo@deped.gov.ph
}

Received: June 16, 2019; Accepted: July 8, 2019; Published: August 6, 2019

\begin{abstract}
Action research plays an important role in education. It enables teachers to discover what went wrong and what could be done to address classroom problems and issues. Consequently, it has now become one of the major professional development concerns for public school teachers in the Philippines. Teachers are encouraged by the Department of Education (DepEd) and the Commission on Higher Education (CHED) to conduct a school-based action research as part of their performance appraisal and evaluation. In addition, it helps the teachers to explore innovative teaching strategies that will suit the needs of the learners. Although, there are promising benefits brought by research, it still remains a challenge among educators due to tight teaching work loads and ancillary roles performed by teachers.

To address this issue, the study aimed to assess the teachers' perception in writing research based on their level of agreement. Its end goal is to help school administrators and education planners to develop capacity building that will help teachers to appreciate more the value of research. It utilized a quantitative-descriptive design. Fifteen (15) teachers were involved in the study that represented the $100 \%$ of the total population of the teaching force in the school. The main data-gathering instrument used was questionnaire. Computation of the weighted mean and ranking were employed in the statistical treatment of data. The results revealed that teachers strongly agreed on the basic principles of action research which signifies their knowledge and understanding of what research is all about. Continuous professional development is suggested to upgrade and strengthen teachers' skills in writing educational research.
\end{abstract}

Keywords: action research, educational research, teachers' perception, writing research

\section{Introduction}

In the Philippines, the Department of Education (DepEd) has issued the DepEd Order No. 39, series 2016 to its constituents for the adoption of "Basic Education Research Agenda" which promotes the conduct of education research in the country. The purpose of which is to identify teachers and department's concerns and problems, and to recommend solutions based on the results and findings of the researches to be conducted. However, doing action research in the Philippine public elementary and secondary schools may not be that easy as many teachers are not equipped with the necessary knowledge on what action research is and how to do it. The Department of Education has been developing ways to make public school teachers knowledgeable and informed about the importance of doing research, unfortunately, many teachers were uninterested.

Teachers categorically, become researchers and have always been linked to teacher's professional development in the field of education. This is to enable the teachers to try new and updated teaching strategies and modern trend pedagogies. This will help them to identify which strategy will work best in a specific classroom setting. It will also address the learner's different needs, and will help in the selection and evaluation of instructional materials for the learner's varied learning styles.

There were very few studies in the Philippines about teachers as researchers and the challenges they faced in doing research compared to other countries which have a greater number of studies. Similarly, in the Philippines, few researchers tried to examine the challenges and issues faced by the teachers in doing research (Ulla et al. 2017). Based on the current trends in Philippine educational system, doing action research is important to identify where the teachers anchor their pedagogical approaches to be used in the teaching and learning process. 
According to Quidmas (2017), to improve the quality performance of master teachers particularly in research, capacity building is very important. DepEd already issued also DepEd Order No. 16 series 2017 entitled "Research Management Guidelines" to localize the research implementation among school levels. Capacity buildings such as seminar that are challenging will be helpful in doing an action research. This will give them opportunity to know more about the importance of action research and have additional experiences that will help them to be more active in action research writing.

A news article pointed out that professional development is considered to be a vehicle through which teachers are being given the chance to enhance their knowledge and skills. In the prevalent form of professional development, action research deliberates the characteristic of effective professional development which supports student's learning. In action research, teachers are able to focus on specific classroom needs of the learners that needed attention. It also helps teachers to critically and analytically evaluate their own pedagogy and to discover what is effective in improving classroom practice. It also provide justification for the actions made that will be helpful for them in building repertoire, identify problems and arrive solutions for improvement (Lejarde, 2017).

According to Peña (2018), professional development is needed for educators to overcome limited applications in teaching and learning. Professional development framework is needed which promotes on-going professional development as teachers must build and acquire new knowledge to build a conceptual understanding of it. Educators should observe models and examples which seek to study instructional and develop practical understanding of a particular research. For curricular and instructional change, educators may also translate new knowledge and ideas into individual and collaborative plans.

Action research is a factor to be considered in improving the school's curriculum for teacher researchers, school administrative staff and other stakeholders in the teaching and learning environment. The main goal of action research is to define ways on how to enhance the lives of the students within the education, and at the same time, to enhance the lives of those professionals who are working within the educational systems. Action research is a valuable practice to undertake for teachers as it offers a collaborative, systematic and participatory process of analysis that actively searches for areas of concern or redress for teachers. Additionally, action research provides teachers with specialized knowledge and technical skills which will require influencing constructive change within classrooms, schools and communities (Galarion, 2018).

According to Marcelo (2018), action research is a logical process to study and collect data that can help teachers and other educational personnel to recognize and develop their practice. Any teacher or a school-based question, topic or problem is important to action research and may be used to start the process of conducting action research. Action research has dramatically gained support from educators, but others do not view it as a legitimate form of research and inquiry. Many researchers view it as an informal, rather than a more rigorous approach to educational approach. The practical and limited aspect of most action research, plus the fact that teachers are the primary researchers leads to distinguishing action research as "applied" research rather than "true" research. It is therefore argued that while this distinction has some validity, it is also true that some action research serves an important role in improving schools.

From the aforecited literatures, different points of view on action research were presented to shed light on its role in education and most especially to teachers. To help teachers upgrade and improve their skills, this study was conducted to assess the perception on writing educational researches in a public school domain.

\subsection{Objective of the Study}

This study assessed the perception of elementary teachers in writing action research as to its parts, types based on the number of writers and scope, and its significance. It specifically focused on how teachers perceive the basic principles and technicalities of action research in the field of education in the Philippines.

\section{Method}

This study utilized the quantitative research. Specifically, it employed the descriptive design to explain the perception of the teachers in writing action research. A survey questionnaire was distributed and answered by the participants. The study included all fifteen (15) elementary teachers in Talisay Elementary School, a public elementary school on the District of Calatagan, Batangas under the Department of Education. Data gathered included the perception of teachers about their knowledge in writing action research and their demographic profile which include age, sex and number of years in service. Weighted mean and ranking were used in the statistical analysis of the data. 


\subsection{Research Design}

Quantitative-descriptive research design was employed in the study. It is a means to describe and examine the perception of the teachers in action research that will serve as variable in the study. The variables, in turn, can be measured, typically on instruments, so that numbered data can be analysed using statistical procedures (Creswell, 2008).

\subsection{Participants}

The participants of the study were fifteen (15) elementary teachers in Talisay Elementary School who were chosen purposively since the lead researcher is part of the current teaching force. It represented the total population of the school in Calatagan District. There are 6 or $40 \%$ of the total number of the respondents who belong to the age bracket of $41-50$. Meanwhile, 5 or $33.33 \%$ of the respondents belong to the age bracket of 21-30. On the other hand, 4 or $26.67 \%$ of the respondents belong to the age bracket of 31-40. It signifies that the leading age bracket of the respondents is 41-50. Teacher's age was grouped into three levels - young age, middle age and old age (Alufohai and Ibhafidon, 2015). Therefore, 21-30 can be categorized as under the young age, 31-40 in the middle age and the 41-50 in the old age. Thus, most of the respondents falls under the old age category. There are 14 or $93.33 \%$ of the total number of the respondents who are female and only 1 or $6.67 \%$ is male. It shows that there are majority of female teachers over male. The reason can be attributed that there are more female who are taking the course of Education than the male which can be affected by the mentality that teaching is a work and profession for females that is why there are more female teachers than the male ones. There are 6 or $40 \%$ of the total number of respondents who belong to 1 to 5 years of service, followed by 4 or $26.67 \%$ of the respondents belong to both 6 to 10 and 16 to 20 years of service. On the other hand, only 1 or $6.67 \%$ of the respondents belong to 11 to 15 years of service. It can be interpreted that most of the teachers who have rendered 1 to 5 years of service are newlyhired teachers compared to those who with 6 years and above experience in teaching profession.

\subsection{Construction and Validation of Instrument}

The researcher took extensive reading of different studies and other samples of questionnaires that will serve as framework to the questionnaire to be developed. With the help of the adviser, the researcher made the first draft of the questionnaire. After the revision in terms of content, format and structure, it was given to three (3) experts who were knowledgeable in the field of education and research for validation.

The questionnaire was set for content validation and minor revision was made. In testing the reliability of the questionnaire, the researcher utilized the Cronbach alpha statistics to obtain and estimate the internal consistency of the questionnaire. Generally, the survey questionnaire obtained an alpha coefficient of 0.95 which implies that the items in the questionnaire were reliable.

\subsection{Data Gathering Procedure}

The researchers secured the permission of the school principal of Talisay Elementary School for the data gathering procedures. Upon approval, the researcher distributed the questionnaires to the respondents of the study. For the ethical considerations, the respondents were assured of that their responses will be treated with utmost confidentiality and that the results will be used for research and professional development purposes. The researchers requested the participants' free time to answer the questionnaire. After the retrieval of the questionnaire, the researcher tabulated and processed the data for the statistical analysis.

\subsection{Statistical Treatment of Data}

Descriptive statistics such as mean and rank were used in the analysis of data. Using the four-point Likert scale, a range was used in the interpretation of the data given below:

\begin{tabular}{cc}
\hline Threshold & Verbal Interpretation \\
\hline $1.00-1.75$ & Strongly Disagree \\
$1.76-2.50$ & Disagree \\
$2.51-3.25$ & Agree \\
$3.26-4.00$ & Strongly Agree \\
\hline
\end{tabular}




\section{Results}

Table 1. Perceptions of Teachers in Writing Action Research in terms of Research Parts

\begin{tabular}{|c|c|c|c|}
\hline Indicators & Weighted Mean & Verbal Interpretation & Rank \\
\hline \multirow{3}{*}{$\begin{array}{l}\text { I understand... } \\
\text { 1. the title of my Action Research to be conducted. } \\
\text { 2. that my research questions should focus on the } \\
\text { problem that needs a solution. }\end{array}$} & & & \\
\hline & 3.47 & Strongly Agree & 2 \\
\hline & 3.2 & Agree & 8 \\
\hline $\begin{array}{l}\text { 3. that the participants of my study should be chosen } \\
\text { based on the set of characteristics needed to give answer } \\
\text { to what is intended to measure of my action research. }\end{array}$ & 3.3 & Strongly Agree & 7 \\
\hline $\begin{array}{l}\text { 4. that my research questions determine the type of } \\
\text { design that I can use and not the other way around. }\end{array}$ & 3.4 & Strongly Agree & 3.5 \\
\hline $\begin{array}{l}\text { 5. that there are different data gathering methods that } \\
\text { I can use in my Action Research. }\end{array}$ & 3.4 & Strongly Agree & 3.5 \\
\hline $\begin{array}{l}6 . \quad \text { that in making my research questionnaire, it should } \\
\text { be valid and reliable. }\end{array}$ & 3.53 & Strongly Agree & 1 \\
\hline $\begin{array}{l}\text { 7. that the results in my research questionnaire should } \\
\text { be discussed thoroughly. }\end{array}$ & 3.4 & Strongly Agree & 3.5 \\
\hline $\begin{array}{l}\text { 8. that my action plan to be developed should be } \\
\text { valuable to the problem that needs a solution. }\end{array}$ & 3.4 & Strongly Agree & 3.5 \\
\hline Grand Mean & 3.39 & Strongly Agree & \\
\hline
\end{tabular}

Overall results show that teachers strongly agreed that they understand the parts of an action research with average weighted mean of 3.39. This means that teachers are knowledgeable in making the research questionnaire valid and reliable. According to Dziedzic (2016), engaging in action research is a "brief, clear, and detailed look at how to complete your own self-directed site-based action research". To do so, the potential action researchers walk through the typical components of an action research project - from question development to literature review to methods and methodology to collecting and analyzing data to reporting findings. The step-by-step approach provides novice action research with a solid grounding in what action research is how one might go about conducting it, and how to share the results.

Table 2. Perceptions of Teachers in Writing Action Research in terms of Research Types Based on the Number of Writers

\begin{tabular}{|c|c|c|c|}
\hline Individual Research & $\begin{array}{c}\text { Weighted } \\
\text { Mean }\end{array}$ & $\begin{array}{c}\text { Verbal } \\
\text { Interpretation } \\
\end{array}$ & Rank \\
\hline \multicolumn{4}{|l|}{ I understand... } \\
\hline $\begin{array}{l}\text { 1. that individual action research is research conducted by } \\
\text { classroom teachers. }\end{array}$ & 3.6 & Strongly Agree & 1 \\
\hline $\begin{array}{l}\text { 2. that this type of research is conducted to analyze a specific } \\
\text { task. }\end{array}$ & 3.47 & Strongly Agree & 2 \\
\hline $\begin{array}{l}\text { 3. that an individual action research is normally done alone by } \\
\text { the teacher. }\end{array}$ & 3 & Agree & 5 \\
\hline $\begin{array}{l}\text { 4. that during this approach the teacher conducts research by } \\
\text { applying a group activity for a certain length of time. }\end{array}$ & 3.13 & Agree & 4 \\
\hline $\begin{array}{l}\text { 5. that the teacher also examines the results, implements } \\
\text { changes, or discards the program if it is not found to be } \\
\text { useful. }\end{array}$ & 3.4 & Strongly Agree & 3 \\
\hline Grand Mean & 3.32 & $\begin{array}{l}\text { Strongly } \\
\text { Agree }\end{array}$ & \\
\hline
\end{tabular}

Overall, the result shows that teachers strongly agree that they understand an individual research as one of the types of an action research with average weighted mean of 3.32. This means that teachers are knowledgeable about 
one of the types of action research which is the individual research as conducted by a single teacher or staff member. Hong and Lawrence (2011) pointed out that in order to better understand what teachers learned through the action research process and how their self-study impacted teaching and learning in their classrooms, qualitative research methods were used to analyze the teachers' projects.

Table 3. Perceptions of Teachers in Writing Action Research in terms of Research Types Based on the Number of Writers

\begin{tabular}{|c|c|c|c|}
\hline Collaborative Research & $\begin{array}{l}\text { Weighted } \\
\text { Mean }\end{array}$ & $\begin{array}{c}\text { Verbal } \\
\text { Interpretation }\end{array}$ & Rank \\
\hline \multicolumn{4}{|l|}{ I understand... } \\
\hline $\begin{array}{l}\text { 1. that collaborative research involves a group of people } \\
\text { researching a specified topic. }\end{array}$ & 3.8 & Strongly Agree & 1 \\
\hline $\begin{array}{l}\text { 2. that with collaborative research, more than one person is } \\
\text { involved in the implementation of the new program. }\end{array}$ & 3.53 & Strongly Agree & 3 \\
\hline $\begin{array}{l}\text { 3. that at many times collaborative research involves both } \\
\text { teachers and the principal of the school. }\end{array}$ & 3.27 & Strongly Agree & 5 \\
\hline $\begin{array}{l}\text { 4. that this type of research offers the collaboration of many } \\
\text { people working jointly on one subject. }\end{array}$ & 3.6 & Strongly Agree & 2 \\
\hline $\begin{array}{l}\text { 5. that the joint collaboration often offers more benefits than } \\
\text { an individual action research approach. }\end{array}$ & 3.4 & Strongly Agree & 4 \\
\hline Grand Mean & 3.52 & Strongly Agree & \\
\hline
\end{tabular}

Overall, the result shows that teachers strongly agree that they understand collaborative research as one of the types of action research with average weighted mean of 3.52. This means that teachers are knowledgeable about collaborative research as one of the types of action research that it is a research done by group about a certain topic. According to Morales (2016), both action research and participatory action research as research models require high level of commitment and involvement from the organization, the individuals or employees and the researchers about the importance of the problem and to the learning that occurs in the process.

Table 4. Perceptions of Teachers in Writing an Action Research in terms of Research Types Based on Scope

\begin{tabular}{|c|c|c|c|}
\hline School-Wide Research & $\begin{array}{l}\text { Weighted } \\
\text { Mean }\end{array}$ & $\begin{array}{c}\text { Verbal } \\
\text { Interpretation }\end{array}$ & Rank \\
\hline \multicolumn{4}{|l|}{ I understand... } \\
\hline $\begin{array}{l}\text { 1. that school-wide research is generally created from a problem } \\
\text { found within an entire school. }\end{array}$ & 3.8 & $\begin{array}{l}\text { Strongly } \\
\text { Agree }\end{array}$ & 1 \\
\hline $\begin{array}{l}\text { 2. that for this type of action research, a school may have concerns } \\
\text { about a school-wide problem. }\end{array}$ & 3.6 & $\begin{array}{l}\text { Strongly } \\
\text { Agree }\end{array}$ & 2.5 \\
\hline $\begin{array}{l}\text { 3. that the entire staff works together through this research to study } \\
\text { the problem, implement changes, and correct the } \\
\text { problem or increase performance. }\end{array}$ & 3.6 & $\begin{array}{l}\text { Strongly } \\
\text { Agree }\end{array}$ & 2.5 \\
\hline Grand Mean & 3.67 & $\begin{array}{l}\text { Strongly } \\
\text { Agree }\end{array}$ & \\
\hline
\end{tabular}

Overall, results show that teachers strongly agree that they understand school-wide research as one of the types of action research with average weighted mean of 3.67. This means that teachers are knowledgeable about Schoolwide research which focuses on the school-based problems. According to McAteer (2013), action research in education has three sections namely: Section One, which is 'Getting to Know Action Research', Section Two, 'Doing Action Research' and the final section is about 'Sharing and Promoting Action Research'. The first section indicated that action research process is a conversation about the evolving nature and practice and theory. There are longer-term usefulness of the disciplines of the action research in providing professionals with an analytical framework that can be used to deconstruct a wide range of professional problems and issues. 
Table 5. Perceptions of Teachers in Writing an Action Research in terms of Research Types Based on Scope

\begin{tabular}{lllc}
\hline \multicolumn{1}{c}{ District-Wide Research } & $\begin{array}{c}\text { Weighted } \\
\text { Mean }\end{array}$ & $\begin{array}{c}\text { Verbal } \\
\text { Interpretation }\end{array}$ & Rank \\
\hline $\begin{array}{l}\text { I understand... } \\
\text { 1. that district-wide research is used for an entire school } \\
\text { district. }\end{array}$ & 3.67 & Strongly Agree & 1 \\
$\begin{array}{l}\text { 2. that this type of action research is usually more community- } \\
\text { based than the other types. }\end{array}$ & 3.33 & Strongly Agree & 4 \\
$\begin{array}{l}\text { 3. that this type may also be used to address organizational } \\
\text { problems within the entire district. }\end{array}$ & 3.6 & Strongly Agree & 2 \\
$\begin{array}{l}\text { 4. that for district-wide research, staff from each school in the } \\
\text { district, collaborates in correcting the problem or finding } \\
\text { ways to improve the situation. }\end{array}$ & 3.4 & Strongly Agree & 3 \\
\hline Grand Mean & 3.5 & Strongly Agree & \\
\hline
\end{tabular}

Overall, the result shows that teachers strongly agree that they understand district-wide research as one of the types of action research with average weighted mean of 3.5. This means that teachers are knowledgeable about Districtwide research which focuses on the problems in the entire district. Miller and Maguire (2009) pointed out that Participatory action research (PAR) provides a framework for recapturing the potential of practitioner inquiry to bring about meaningful change. PAR expands the notion of researcher to include a range of stakeholders who collaboratively engage in all phases of the action-reflection cycle. The intentional focus on collaborative research, action for social change, and participant education shifts inquiry from an individual to a collective endeavor, intentionally aimed at transformative personal, is organizational and structural change.

Table 6. Perceptions of Teachers in Writing an Action Research in terms of Significance

\begin{tabular}{llll}
\hline Indicators & $\begin{array}{c}\text { Weighted } \\
\text { Mean }\end{array}$ & $\begin{array}{c}\text { Verbal } \\
\text { Interpretation }\end{array}$ & Rank \\
\hline $\begin{array}{l}\text { I understand... } \\
\text { 1. } \begin{array}{l}\text { that writing an action research can offer me multiple, } \\
\text { beneficial opportunities which includes facilitating the }\end{array}\end{array}$ & Strongly Agree & 2.5 \\
$\begin{array}{l}\text { professional development of teachers. } \\
\text { that it provides me with new knowledge and } \\
\text { understanding about how to improve educational } \\
\text { practices. }\end{array}$ & Strongly Agree & 1 \\
$\begin{array}{l}\text { 3. } \\
\text { that it helps me to resolve significant problems in } \\
\text { classrooms and schools. }\end{array}$ & Strongly Agree & 4.5 \\
$\begin{array}{l}\text { that it encourages me to become continuous learner } \\
\text { within my classroom and school. }\end{array}$ & Strongly Agree & 2.5 \\
$\begin{array}{l}\text { 5. } \\
\text { that it can help me in my professional disposition as a } \\
\text { teacher. }\end{array}$ & 3.73 & Strongly Agree & 4.5 \\
\hline Grand Mean & 3.78 & Strongly Agree & \\
\hline
\end{tabular}

Overall, the results show that teachers strongly agree that they understand the significance of action research with average weighted mean of 3.78. This means that teachers are knowledgeable in the significance of action research that it serves as a source of new understanding in improving the educational practices. According to Abuda (2016) in her news article "Bridging the gap between research and practice", it is then necessary for teachers to grow professionally by upgrading themselves on current issues. The Action Research Congress was a good avenue for teachers to share their research findings and as school community address existing problems. It is also one way a school acts cooperatively to solve a problem, thus bridging the gap between research and practice. Conducting Action Research is tedious but indeed rewarding. 
Table 7. Summary of Results

\begin{tabular}{lll}
\hline Indicators & Weighted Mean & $\begin{array}{l}\text { Verbal } \\
\text { Interpretation }\end{array}$ \\
\hline $\begin{array}{l}\text { Perceptions of Teachers in Writing Action Research in terms of } \\
\text { Research Parts }\end{array}$ & 3.39 & Strongly Agree \\
$\begin{array}{l}\text { Perceptions of Teachers in Writing Action Research in terms of } \\
\text { Research Types Based on the Number of Writers : Individual } \\
\text { Research }\end{array}$ & 3.32 & Strongly Agree \\
$\begin{array}{l}\text { Perceptions of Teachers in Writing Action Research in terms of } \\
\text { Research Types Based on the Number of Writers : Collaborative } \\
\text { Research }\end{array}$ & 3.52 & Strongly Agree \\
$\begin{array}{l}\text { Perceptions of Teachers in Writing an Action Research in terms of } \\
\text { Research Types Based on Scope: School-wide Research } \\
\text { Perceptions of Teachers in Writing an Action Research in terms of } \\
\text { Research Types Based on Scope: District-wide Research }\end{array}$ & 3.67 & Strongly Agree \\
\hline $\begin{array}{l}\text { Perceptions of Teachers in Writing an Action Research in terms of } \\
\text { Significance }\end{array}$ & 3.78 & Strongly Agree \\
\hline Grand Mean & 3.53 & Strongly Agree \\
\hline
\end{tabular}

Overall result showed that teachers strongly agree that they are knowledgeable with the different parts of an action research. They also understand that there are two types of action research based on the number of writers namely: Individual and Collaborative research and the other two types based on scope are the school-wide and districtwide research. Teachers also strongly agreed that they know the significance of conducting and writing an action research as it will help in finding solutions to problems in a school or in the community. Moreover, they understand that research will improve the different pedagogies in a classroom setting so that the learners will be more active and engaging in the learning process.

\section{Discussion}

The results of this study revealed that teachers are knowledgeable in writing an action research in terms of its parts, different types and significance based on their agreement of the basic principles of writing research. It is suggested that continuous professional development focusing on research capacity building be done to upgrade and strengthen teachers' skills in writing educational research to improve the teaching and learning process. In light of the findings, a model is developed to localize the recommendation of this study.

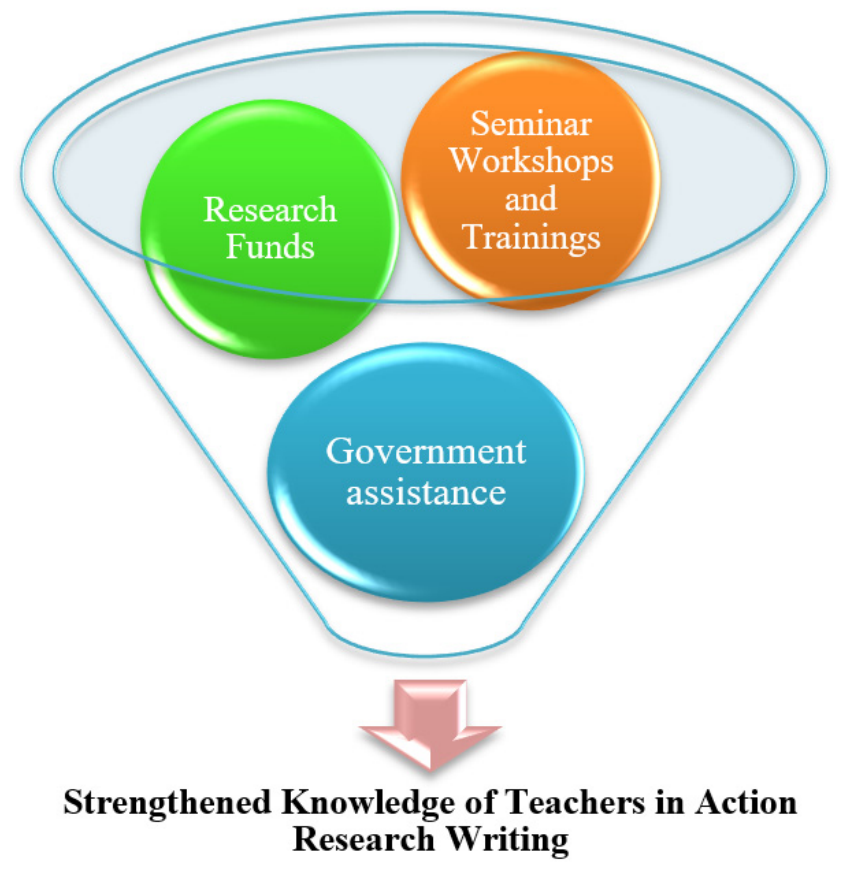

Figure 1. 
Using the above model, it is reflected that in order for teachers to have additional knowledge and in-depth understanding of writing action research, there are three important factors needed: 1) more seminar workshops and trainings about action research; 2) research funds and other resources and; 3) government assistance so that the production of quality researches will be possible and for teachers to be encouraged in becoming active researchers.

\section{Conclusions and Recommendations}

Based on the findings of this study, teachers are knowledgeable in writing an action research in terms of its basic principles.

The following recommendations are hereby endorsed: that there should be gender-sensitive research training and other profiles of the teachers should be considered in the capacity-building. Extensive seminar workshops about action research should be employed by the Department of Education for additional knowledge and in-depth understanding of teachers on writing research. It is also recommended that teachers should do action research not just for the sake of compliance but to improve their skills in writing action research.

\section{Acknowledgements}

The researcher would like to acknowledge the effort, time and help given by the participants of the study who happened to be her co-teachers, without them, this research will not be completed. The researchers contributed equally to this study in terms of preparing the manuscript, editing, revising and statistical analysis of the data.

\section{References}

Abuda, J. A. (2016). Bridging the gap between research and practice. Sun Star Baguio.

Alufohai, P. J., \& Ibhafidon, H. E. (2015). Influence of Teachers' Age, Marital Status And Gender On Students ' Accademic-Achievement. Retrieved from http://www.multidisciplinaryjournals.com/wpcontent/uploads /2015/07/paperINFLUENCE-OF-TEACHERS\%E2\%80\%99-AGEMARITAL-STATUS.pdf

Creswell, J. W., \& Clark, P. (2008). The selection of Research Design (pp. 3-5). Sage Publication. Retrieved from https://www.sagepub.com/sites/default/files/upmbinaries/22780_Chapter_1.pdf

Dziedzic, M. (2016). Engaging in Action Research: A Practical Guide to Teacher-Conducted Research for educators \& School Leaders. New Prairie Press, Canada. https://doi.org/10.4148/2470-6353.1025

Galarion, M. P. (2018). Action Research: Why it matters? Sun Star Pampanga.

Hong, C. E., \& Lawrence, S. A. (2011). Action Research in Teacher Education: Classroom Inquiry, Reflection, and Data-Driven Decision Making. Journal of Inquiry \& Action in_Education.

Lejarde, B. L. (2017). Action Research as an Integral Part in the Teaching Profession. Sun Star Pampanga.

Marcelo, L. M. (2018). Contracting School-Based Action Research. Panay News.

McAteer, M. (2013). Action Research in Education. Sage Publishing, London. https://doi.org/10.4135/9781473913967

Miller, M. B., \& Maguire, P. (2009). Participatory action research: Contributions to the development of practitioner inquiry in education. Educational Action Research Journal.

Morales, M. E. (2016). Participatory Action Research (PAR) cum Action Research (AR) in Teacher Professional Development: A Literature Review. International Journal of Research in Education and Science (IJRES). https://doi.org/10.21890/ijres.01395

Peña, C. D. (2018). Developing Professionally. Sun Star Pampanga.

Quidmas, J. S. (2017). Master Teachers' seminar workshop on capability building on Action Research and Basic Research Proposal Writing. Sun Star Baguio.

Ulla et al. (2017). The importance of action research in teacher education programs. Retrieved from http://www.iier.org.au/iier23/hine.pdf

\section{Copyrights}

Copyright for this article is retained by the author(s), with first publication rights granted to the journal.

This is an open-access article distributed under the terms and conditions of the Creative Commons Attribution license (http://creativecommons.org/licenses/by/4.0/). 